\title{
An Improved System for Shoot Regeneration from Stem Explants of Lombardy Poplar (Populus nigra L. var. italica Koehne)
}

\author{
Kamal Kanti Biswas ${ }^{1}$, Takeshi Mohri ${ }^{2}$, Satoshi Kogawara ${ }^{2}$, Yoshihiro Hase ${ }^{1}$, Issay Narumi ${ }^{1}$, \\ Yutaka Oono ${ }^{1}$ \\ ${ }^{1}$ Medical and Biotechnological Application Division, Japan Atomic Energy Agency (JAEA), Takasaki, Japan; ${ }^{2}$ Forestry and Forest \\ Products Research Institute (FFPRI), Tsukuba, Japan. \\ Email: biswas.kamal@jaea.go.jp
}

Received July $5^{\text {th }}$, 2012; revised July $30^{\text {th }}$, 2012; accepted August $10^{\text {th }}, 2012$

\begin{abstract}
We developed a system for the regeneration of Lombardy poplar (Populus nigra L. var. italica) shoots from internodal stem explants. Using this system, shoots regenerated from 87\% of the stem explants placed on Murashige and Skoog (MS) medium supplemented with $0.1 \mathrm{mg} / \mathrm{L}$ indole-3-acetic acid and $0.5 \mathrm{mg} / \mathrm{L}$ benzylaminopurine without undergoing callus formation. About $80 \%$ of the in vitro regenerated shoots developed roots on MS medium supplemented with 0.5 $\mathrm{mg} / \mathrm{L}$ indole-3-butyric acid and $0.02 \mathrm{mg} / \mathrm{L}$ 1-naphthylacetic acid. Well-rooted seven-to eight-week-old regenerated plants could be transferred to soil for further growth and the survival rate of such plants after three weeks was $88 \%$. The protocol presented here is simple and economical because it does not rely on pre-incubation in callus induction medium or repeated subculture in shoot induction medium containing trans-zeatin, an expensive substance. The in vitro regeneration system presented here could be used for evaluation of radiation sensitivity for Lombardy poplar tissues.
\end{abstract}

Keywords: Lombardy Poplar; Shoot Regeneration; Stem Explants; Auxin and Benzylaminopurine; Radiation Sensitivity

\section{Introduction}

Poplars are of growing scientific importance due to their small genome size, short rotation cycle, ability to undergo in vitro regeneration, and ease of transformation and vegetative propagation. These important traits, coupled with the existence of a library of full-length enriched expressed sequence tags [1] and availability of the genome sequence of Populus tricocarpa, have established poplar as a model system in molecular genetics [2-5] and tree physiology [6-8] studies. Furthermore, these rapidly growing plants, which have the potential to enhance wood supplies for the plywood, hardboard, pulp, and paper industries, represent a commercially important resource [9].

In vitro plant regeneration of Lombardy poplar [11] or its close hybrids [10,12-14] was achieved from leaf or stem explants. These methods consists of two steps of tissue culture stages; first, stem or leaf explants were incubated on the medium containing high concentration of plant hormone auxin (in most case, it is called callus inducing medium, CIM) for several days then transferred to shoot induction medium (SIM) that dominantly con- tains plant hormone cytokinin. The system is also available for Agrobacterium-mediated gene transformation $[10,11,15]$. In an early study of Lombardy poplar regeneration by Mohri et al. [15], $0.5 \mathrm{mg} / \mathrm{L}$ 2,4-dichlorophenoxyacetic acid (2,4-D) was added to CIM for calli induction. Then, four weeks old calli developed in CIM were repeatedly subcultured in SIM containing $2 \mathrm{mg} / \mathrm{L}$ trans-zeatin and $0.2 \mathrm{mg} / \mathrm{L}$ benzylaminopurine (BA), followed by re-transfer to root induction medium (RIM). In later by Nishiguchi et al. [11], much simple regeneration method had been developed for Lombardy poplar regeneration, without callus formation. But, still they relied on pre incubation of explants in CIM $(0.5 \mathrm{mg} / \mathrm{L} \mathrm{2,4-D}$ and $1 \mathrm{mg} / \mathrm{L} \mathrm{BA}$ ) for 6 days. There after, pre incubated explants in CIM were subcultured in SIM $(0.5 \mathrm{mg} / \mathrm{L}$ zeatin and $0.1 \mathrm{mg} / \mathrm{L} \mathrm{BA}$ ) for several times, followed by re-transfer to RIM. However, in our experience, we were unable to perform efficient shoot regeneration with these protocols. Thus, we tried to re-optimize shoot regeneration protocol for Lombardy poplar by using different types of auxins and cytokinins at various concentrations. Here, we report a simple shoot regeneration protocol from stem explants of Lombardy poplar that is charac- 
terized by unrequisite of pre-incubation step in CIM.

\section{Materials and Methods}

\subsection{Plant Materials, Growth Condition and Surface Sterilization}

Lombardy poplar plants were propagated in our laboratory from cuttings of poplars obtained from the Forestry and Forest Products Research Institute, Tsukuba, Ibaraki, Japan. Donor plants were grown in pots containing a 1:1 mixture of vermiculite and Metro-Mix 350 (Scotts-Sierra Horticultural Products Company, Marysville, $\mathrm{OH}$ ) at $26^{\circ} \mathrm{C}$ under fluorescent tubes $\left(90 \mu \mathrm{E} \cdot \mathrm{m}^{-2} \cdot \mathrm{s}^{-1}, 16\right.$-h photoperiod). The relative humidity was kept at $70 \%$. The plants received weekly applications of Hyponex solution (1:1000) and were watered daily.

In preliminary experiments, surface sterilized explants $(1 \mathrm{~cm})$ from leaves, petioles, and stems were used to examine regeneration proficiency to a range of different concentration of 2,4-D, indole-3-acetic acid (IAA), naphthylacetic acid (NAA), thidiazuron (TDZ), zeatin and BA, singly or in combination. But, efficient and reproducible regeneration were obtained only with stem explants in preliminary experiments. Thus, only internodal stem explants were used for remaining experiments of this study. Internodal stem explants were excised from newly growing branches of 3- to 4-month-old donor plants, cut to $1-\mathrm{cm}$ segments, and divided vertically into halves (Figure 1A). Surface microorganisms were removed from the explants by thorough washing under running water for $20 \mathrm{~min}$, followed by treatment with sodium hypo-chlorite solution (15\%) for $20 \mathrm{~min}$. The explants were then washed three times for 20 min each with sterile water.

\subsection{Culturing Tissues and Shoot Regeneration}

For plantlet regeneration, the surface-sterilized stem explants were cultured on Petri dishes containing Murashige and Skoog (MS) basal medium [16] supplemented with $30 \mathrm{~g} / \mathrm{L}$ sucrose, $1 \mathrm{ml} / \mathrm{L}$ vitamin $\mathrm{B} 5,3 \mathrm{~g} / \mathrm{L}$ Gelrite (Wako, Osaka, Japan) and various concentrations of IAA, NAA and/or cytokinin (BA) (Table 1). The $\mathrm{pH}$ of media was adjusted to 5.8 prior to autoclaving at $121^{\circ} \mathrm{C}$ for 20 min. The explant cultures were maintained at $26^{\circ} \mathrm{C}$ under 16-h light and 8-h dark intervals in a growth chamber and subcultured in every 2 weeks.

\subsection{Root Induction}

For root induction, regenerated shoots were separated and cultured on MS medium supplemented with $30 \mathrm{~g} / \mathrm{L}$ sucrose, $1 \mathrm{ml} / \mathrm{L}$ vitamin B5, 2 g/L Gelrite, $4 \mathrm{~g} / \mathrm{L}$ agar and various concentrations of indole-3-butyric acid (IBA) and

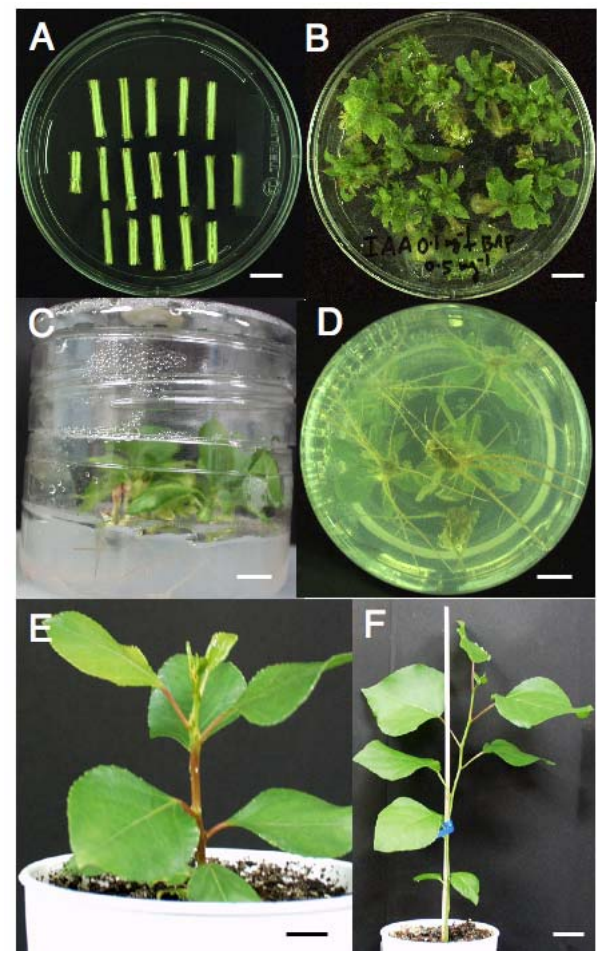

Figure 1. Direct plant regeneration of Lombardy poplar. (A) Vertically divided internodal stem segments were used as starting materials; (B) Shoot regeneration on medium supplemented with $0.1 \mathrm{mg} / \mathrm{L}$ IAA and $0.5 \mathrm{mg} / \mathrm{L} \mathrm{BA}$; (C) and (D) Root development [side view (C) and bottom view (D)] in seven-to-eight-week-old in vitro raised plants on MS medium supplemented with $0.5 \mathrm{mg} / \mathrm{L}$ IBA, $0.02 \mathrm{mg} / \mathrm{L}$ NAA, 4 g/L agar and $2 \mathrm{~g} / \mathrm{L}$ Gelrite; (E) Regenerated plant growing in a soil mixture of vermiculite and Metro-Mix 350 (1:1); (F) Well-established and hardened in vitro raised Populus plant growing in soil mixture. Bars indicate $1 \mathrm{~cm}$ (A)-(E) and 2 cm (F).

Table 1. Direct shoot regeneration from internodal stem explants of Lombardy poplar.

\begin{tabular}{|c|c|c|c|c|c|}
\hline \multicolumn{4}{|c|}{ Treatment (mg/L) } & \multirow{2}{*}{$\begin{array}{c}\text { Shoot } \\
\text { induction }(\%)^{\mathrm{a}}\end{array}$} & \multirow{2}{*}{$\begin{array}{c}\text { Number of } \\
\text { shoots per } \\
\text { explant }^{\mathrm{a}}\end{array}$} \\
\hline IAA & NAA & 2,4-D & BA & & \\
\hline 0 & 0 & 0 & 0 & 0 & 0 \\
\hline 0 & 0 & 0.5 & 0.5 & 0 & 0 \\
\hline 0.1 & 0 & 0.5 & 0.5 & 0 & 0 \\
\hline 0.1 & 0 & 0 & 0.1 & $46 \pm 2.31$ & $1.87 \pm 0.11$ \\
\hline 0.1 & 0 & 0 & 0.2 & $51 \pm 2.40$ & $1.96 \pm 0.07$ \\
\hline 0.1 & 0 & 0 & 0.5 & $87 \pm 3.71$ & $3.87 \pm 0.09$ \\
\hline 0.2 & 0 & 0 & 1 & $87 \pm 4.81$ & $3.63 \pm 0.08$ \\
\hline 0.5 & 0 & 0 & 0.5 & $45 \pm 3.71$ & $2.13 \pm 0.12$ \\
\hline 0 & 0.1 & 0 & 0.5 & $79 \pm 4.37$ & $3.18 \pm 0.10$ \\
\hline 0 & 0.2 & 0 & 0.5 & $83 \pm 3.33$ & $3.55 \pm 0.07$ \\
\hline 0 & 0.5 & 0 & 0.5 & $39 \pm 4.80$ & $2.05 \pm 0.07$ \\
\hline
\end{tabular}

${ }^{\mathrm{a}}$ Results represent means \pm standard errors (SEs) of at least three replicated experiments. Each experiment contained 40 to 50 explants. Measurements were taken after five weeks of culture. 
NAA. Again, the $\mathrm{pH}$ of the medium was adjusted to 5.8 .

\subsection{Irradiation of Tissues}

For investigation of radiation dose response relationship on viability test and growth proficiency of regenerated shoots, stem explants were excised to $1 \mathrm{~cm}$, surface sterilized, divided vertically into halves and cultured on medium with $0.1 \mathrm{mg} / \mathrm{L}$ IAA and $0.5 \mathrm{mg} / \mathrm{L}$ BA in Petri dishes. One week after from culture, Petri dishes containing stem segments were subjected for irradiation with a range of doses ( $0 \mathrm{~Gy}$ to $30 \mathrm{~Gy}$ ). The explants were exposed to $320 \mathrm{MeV}$ carbon ions accelerated by the azimuthally varying field cyclotron $[22,23]$ or gamma rays. Gamma rays obtained from ${ }^{60} \mathrm{Co}$ source maintaining at Japan Atomic Energy Agency (Takasaki, Japan). Irradiation time for gamma rays was fixed to $30 \mathrm{~min}$. Shoots above $1 \mathrm{~cm}$ in length at five weeks after irradiation were counted as regenerated shoots. Regeneration ratio was calculated with dividing the number of stem explants that produce regenerated shoots by total number of stem explants irradiated. The regeneration ratio of non-irradiated control stems was plotted as $100 \%$.

\section{Results and Discussion}

\subsection{Direct Shoot Regeneration}

In preliminary experiments, we cultured explants from leaves, petioles, and shoots to medium supplemented with different concentrations of 2,4-D, IAA, NAA, TDZ, zeatin and BA, singly or in combination (data not shown). Leaf and petiole explants did not develop any robust calli or shoots on any of the media mentioned above. On the other hand, stem explants developed calli on medium supplemented with $0.5 \mathrm{mg} / \mathrm{L} \mathrm{2,4-D}$ and $0.5 \mathrm{mg} / \mathrm{L} \mathrm{BA}$; however, no shoots emerged from these calli until five weeks of culture (Table 1). Interestingly, we found that direct shoot regeneration occurred when stem explants were cultured on medium supplemented with NAA and IAA in combination with BA (Table 1 and Figure 1(B)).

Over $87 \%$ of the stem explants produced at least one shoot on medium supplemented with $0.1 \mathrm{mg} / \mathrm{L}$ IAA and $0.5 \mathrm{mg} / \mathrm{L}$ BA. The average number of shoots per explant was $3.87 \pm 0.09$ (Table 1). A further increase of IAA to $0.2 \mathrm{mg} / \mathrm{L}$ or $0.5 \mathrm{mg} / \mathrm{L}$ and BA to $1 \mathrm{mg} / \mathrm{L}$ failed to improve the regeneration efficiency. Thus, we used 0.1 $\mathrm{mg} / \mathrm{L}$ IAA and $0.5 \mathrm{mg} / \mathrm{L} \mathrm{BA}$ for the direct regeneration of Lombardy poplar in this study. Application of the synthetic auxin analog NAA yielded similar results as IAA. Over $83 \%$ of the explants induced shoots on medium supplemented with $0.2 \mathrm{mg} / \mathrm{L}$ NAA and $0.5 \mathrm{mg} / \mathrm{L}$ $\mathrm{BA}$, and the average number of shoots per explant was $3.55+0.07$ (Table 1). Once again, an increased NAA concentration $(0.5 \mathrm{mg} / \mathrm{L})$ failed to improve the regenera- tion efficiency (Table 1). In Eastern Cottonwood (Populus deltoides Bartram ex Marsh.), addition of cytokinin (1 mg/L zeatin) alone resulted in the most efficient shoot regeneration from stem explants in woody plant medium (WPM) [17]. However, we found that cytokinin alone could not stimulate the growth of calli or shoots in Lombardy poplar and an optimal combination of auxin and cytokinin (BA) was required for direct shoot regeneration. This indicates that the optimal hormone concentration for direct shoot regeneration in poplar is genotype specific. Alternatively, the difference in response might be for the reason of different basal medium, although there is no major difference between the composition of WPM and MS. Thus, for efficient regeneration, appropriate combination and concentration of growth regulators need to be determined precisely.

\subsection{Root Induction}

To optimize root induction conditions, the directly regenerated shoots were cultured on media containing IBA and NAA. In agreement with a report [11], we found that a combination of $0.5 \mathrm{mg} / \mathrm{L}$ IBA and $0.02 \mathrm{mg} / \mathrm{L}$ NAA was the most effective dose for root development in Lombardy poplar (Figure 1(C) and 1(D)), although $0.5 \mathrm{mg} / \mathrm{L}$ IBA alone could induce roots in $50 \%$ of the regenerated shoots (Table 2). Doubling the concentration of IBA and NAA in the medium did not improve the root induction efficiency (Table 2). The average number of roots per shoot in the presence of $0.5 \mathrm{mg} / \mathrm{L} \mathrm{IBA}$ and $0.02 \mathrm{mg} / \mathrm{L}$ NAA was $5.2 \pm 0.34$ (Table 2).

We separated the well-rooted plants that were approximately seven weeks old from the culture medium, transferred them to pots containing a 1:1 mixture of vermiculite and Metro-Mix 350 and incubated them at $26^{\circ} \mathrm{C}$ under a 16/8 h light/dark regimen. Figure 1(E) shows a regenerated plant growing in soil mixture. Initially, the potted plants were covered with clear plastic bags to protect them from any direct physical stress, and the plants

Table 2. Root induction in the regenerated shoots.

\begin{tabular}{cccc}
\hline \multicolumn{2}{c}{ Treatment $(\mathrm{mg} / \mathrm{L})$} & $\begin{array}{c}\text { Root induction } \\
(\%)^{\mathrm{a}}\end{array}$ & $\begin{array}{c}\text { Number of roots } \\
\text { per shoot }^{\mathrm{a}}\end{array}$ \\
\cline { 1 - 2 } IBA & NAA & 0 & 0 \\
0.5 & 0 & $50.00 \pm 4.33$ & $3.6 \pm 0.24$ \\
0 & 0.02 & 0 & - \\
0.5 & 0.01 & $60.83 \pm 4.41$ & $3.67 \pm 0.12$ \\
0.5 & 0.02 & $78.33 \pm 3.00$ & $5.2 \pm 0.34$ \\
1 & 0.04 & $75.83 \pm 3.63$ & $5.1 \pm 0.31$ \\
\hline
\end{tabular}

${ }^{\mathrm{a}}$ Results represent means \pm SEs of at least three replicated experiments. Each experiment contained 40 to 50 regenerated shoots. Measurements were taken after seven weeks of culture. 
were unwrapped after 7 - 10 days. The in vitro raised poplar plants grew well and showed a high percentage of survival rates (88\%) at three weeks of growth in soil. Healthy plants were transferred to larger pots with fresh soil. Well-established and hardened plants were allowed to grow (Figure 1(F)) in an incubator with weekly applications of Hyponex solution (1:1000).

\subsection{Test of Radiation Sensitivity of Tissues}

The direct shoot regeneration protocol developed in this study can be used to estimate radiation sensitivity of the tissues, which is initial requirement for a strategy of tissueculture-mediated screening mutants with ionizing radiation. Figure 2 represents dose response relationship curves for carbon ion-beam (Figure 2(a)) and gamma-ray (Figure 2(b)) irradiation on viability test and growth proficiency of in vitro regenerated Lombardy poplar shoots. No visible decrease in growth of regenerated shoots was found up to the irradiation dose of $2.5 \mathrm{~Gy}$ and $5 \mathrm{~Gy}$ for ion beams and gamma rays, respectively. Hence, irradiation with these doses to stem explants of Lombardy poplar hardly affects survival ability of regenerated shoots. It is relevant to mention that now a day, ionizing radiation is attracting increasing attention as a new mutagen $[22,23]$. Various novel mutants of a wide variety of plants, which include Arabidopsis thaliana, Lotus japonicus, tobacco, rice, verbena, rose, carnation, Torenia, petunia, and Hinoki cypress, have been obtained via ion-beam irradiation [24]. Similarly, soybean mutant lacking lipoxygenases was identified by gamma-ray irradiation [25]. Thus, using this strategy, isolation of mutants would be achievable in poplar, as well.

\section{Conclusion}

We found that shoot regeneration from Lombardy poplar stem segments can be achieved by a simple procedure, in which pre-culture in CIM is not necessary. Similar procedure is reported in Eastern Cottonwood (P. deltoides) [17-19] and male Himalayan poplar ( $P$. ciliata) [20]. No callus induction in this method might be another advantage, because it is well known that plants regenerated via a callus phase may differ from the mother plant due to somaclonal variations [21]. The present protocol is also economical, because it results high frequency (87\%) direct shoot regeneration without trans-zeatin, an expensive substance that have used in the previous protocols of

Table 3. Comparison of regeneration systems in Lombary poplar (Populus nigra cv. italica) and related species.

\begin{tabular}{|c|c|c|c|c|c|c|}
\hline $\begin{array}{l}\text { Genetic } \\
\text { background }\end{array}$ & $\begin{array}{l}\text { No. of media } \\
\text { used for shoot } \\
\text { regeneration* }\end{array}$ & $\begin{array}{c}\text { Name of } \\
\text { media }\end{array}$ & $\begin{array}{l}\text { Growth regulators } \\
(\mathrm{mg} / \mathrm{L})\end{array}$ & $\begin{array}{l}\text { Explant } \\
\text { tissue type }\end{array}$ & $\begin{array}{c}\text { Incubation } \\
\text { period (week) }\end{array}$ & Reference \\
\hline \multirow{2}{*}{$\begin{array}{l}\text { Populus nigra L. } \\
\text { var italica Koehne }\end{array}$} & \multirow{2}{*}{1} & SIM & IAA $(0.1)+$ BA (0.5) & \multirow{2}{*}{ Stem } & \multirow{2}{*}{8} & \multirow{2}{*}{ Present study } \\
\hline & & RIM & $\operatorname{IBA}(0.5)+$ NAA $(0.02)$ & & & \\
\hline \multirow{3}{*}{$\begin{array}{l}\text { Populus nigra L. } \\
\text { var italica Koehne }\end{array}$} & \multirow{3}{*}{2} & CIM & 2,4-D (0.5) & \multirow{3}{*}{ Stem } & \multirow{3}{*}{10} & \multirow{3}{*}[15]{} \\
\hline & & SIM & $t$-zeatin $(2.0)+$ BA $(0.2)$ & & & \\
\hline & & RIM & IBA (0.5) + NAA (0.02) & & & \\
\hline \multirow{4}{*}{$\begin{array}{l}\text { Populus nigra L. } \\
\text { var italica Koehne }\end{array}$} & \multirow{3}{*}{2} & CIM & $2,4-\mathrm{D}(0.5)+\mathrm{BA}(1.0)$ & \multirow{3}{*}{ Stem } & \multirow{3}{*}{13} & \multirow{3}{*}{ [11] } \\
\hline & & SIM & $t$-zeatin $(0.5)+$ BA (0.1) & & & \\
\hline & & RIM & IBA $(0.5)+$ NAA $(0.02)$ & & & \\
\hline & \multirow{3}{*}{2} & CIM & NAA $(0.2)+\mathrm{BA}(0.5)$ & \multirow{3}{*}{ Leaf } & \multirow{3}{*}{$13 \sim$} & \multirow{3}{*}{ [10] } \\
\hline \multirow[t]{2}{*}{ Populus nigra L. } & & SIM & NAA $(0.05)+$ BA (0.5) & & & \\
\hline & & RIM & None & & & \\
\hline \multirow{3}{*}{$\begin{array}{l}\text { Populus nigra } \\
\times P \text {. pyramidales }\end{array}$} & \multirow{3}{*}{2} & CIM & NAA $(0.5)+$ BA (1.0) & \multirow{3}{*}{ Leaf } & \multirow{3}{*}{ INT } & \multirow{3}{*}{ [14] } \\
\hline & & SIM & NAA $(0.25)+$ BA $(0.6)$ & & & \\
\hline & & RIM & NAA $(0.1)+B A(0.1)$ & & & \\
\hline \multirow{4}{*}{$\begin{array}{l}\text { Populus nigra var thevestina } \\
\times(P . \text { diversifolia }+ \\
\text { P. tomentosa })\end{array}$} & \multirow{3}{*}{2} & CIM & $\mathrm{IAA}(0.1)+\mathrm{BA}(0.5)$ & \multirow{3}{*}{ Leaf } & \multirow{3}{*}{ INT } & \multirow{3}{*}{ [12] } \\
\hline & & SIM & NAA $(0.01)+$ BA (0.5) & & & \\
\hline & & RIM & IAA (0.8) & & & \\
\hline & \multirow{3}{*}{2} & CIM & $\operatorname{IBA}(0.1)+\mathrm{BA}(0.5)$ & \multirow{3}{*}{ Leaf } & \multirow{3}{*}{ INT } & \multirow{3}{*}{ [13] } \\
\hline \multirow[t]{2}{*}{ Populus nigra var thevestina } & & SIM & $\operatorname{IBA}(0.1)+\mathrm{BA}(1.0)$ & & & \\
\hline & & RIM & IBA (1.0) & & & \\
\hline
\end{tabular}

*RIM is not included. INT: Information not traceable. 

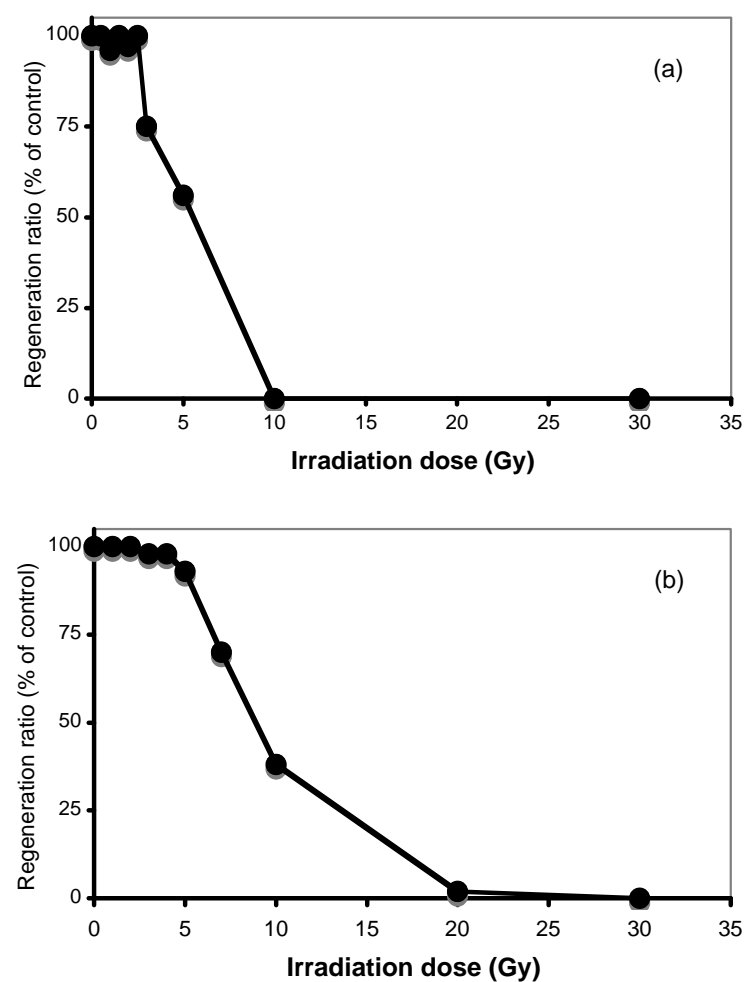

Figure 2. Dose response relationship curves for carbon ionbeam (a) and gamma-ray (b) irradiation on regeneration ratio of in vitro raised Lombardy poplar. Shoots above $1 \mathrm{~cm}$ in length at five weeks after irradiation were counted as regenerated shoots. Regeneration ratio was calculated with dividing the number of stem explants that produce regenerated shoots by total number of stem explants irradiated. The regeneration ratio of non-irradiated control stems was plotted as $100 \%$.

Lombardy poplar regeneration (Table 3) [11,15,17]. Our method is able to produce and perpetuate a large number of disease-free Lombardy poplar plants, and will thus benefit physiological and genetic studies of hardwood plants by providing a constant supply of competent and efficient plant materials.

\section{Acknowledgements}

The authors wish to express their gratitude to Dr. Kenji Shinohara, FFPRI, Tsukuba for providing Populus nigra plants.

\section{REFERENCES}

[1] T. Igasaki, Y. Watanabe, M. Nishiguchi and N. Kotoda, "The Flowering Locus T/Terminal Flower1 Family in Lombardy Poplar,” Plant Cell Physiology, Vol. 49, No. 3, 2008, pp. 291-300. doi:10.1093/pcp/pcn010

[2] K.-H. Han, C. Ma and S. H. Strauss, “An Agrobacterium tumefaciens Transformation Protocol Effective on a Variety of Cottonwood Hybrids (Genus Populus),” Plant Cell
Report, Vol. 19, No. 3, 2000, pp. 315-320. doi:10.1007/s002990050019

[3] W. H. Dai, Z. M. Cheng and W. Sargent, "Plant Regeneration and Agrobacterium-Mediated Transformation of Two Elite Aspen Hybrid Clones from in Vitro Leaf Tissues,” In Vitro Cellular and Developmental Biology-Plant, Vol. 39, No. 6, 2003, pp. 6-11. doi:10.1079/IVP2002355

[4] N. R. Street, O. Skogström, A. Sjödin, J. Tucker, R. A. Maricela, P, Nilsson, S. Jansson and G. Taylor, "The Genetics and Genomics of Drought Response in Populus," The Plant Journal, Vol. 48, No. 3, 2006, pp. 321-341. doi:10.1111/j.1365-313X.2006.02864.X

[5] S. Raj, K. Bräutigam, E. T. Hamanishi, O. Wilkins, B. R. Thomas, W. Schroeder, S. D. Mansfield, A. L. Plant and M. M. Campbell, "Clone History Shapes Populus Drought Responses," Proceedings of the National Academy of Sciences of the United States of America, Vol. 108, No. 30, 2011, pp. 12521-12526. doi:10.1073/pnas.1103341108

[6] S. H. Son and R. B. Hall, "Multiple Shoot Regeneration from Root Organ Cultures of Populus alba $\times$ P. grandidentata," Plant Cell Tissue and Organ Culture, Vol. 20, No. 1, 1990, pp. 53-57. doi:10.1007/BF00034757

[7] T. Ruttink, M. Arend, K. Morreel, V. Strome, S. Rombauts, J. Fromm, R. P. Bhalerao, W. Boerjan and A. Rohde, "A Molecular Timetable for Apical Bud Formation and Dormancy Induction in Poplar," The Plant Cell, Vol. 19, No. 8, 2007, pp. 2370-2390. doi:10.1105/tpc.107.052811

[8] A. Caruso, F. Chefdor, S. Carpin, C. Depierreux, F. M. Delmotte, G. Kahlem and D. Morabito, "Physiological Characterization and Identification of Genes Differentially Expressed in Response to Drought Induced by PEG 6000 in Populus canadensis Leaves," Journal of Plant Physiology, Vol. 165, No. 9, 2008, pp. 932-941. doi:10.1016/j.jplph.2007.04.006

[9] A. Matthias and J. Fromn, "Seasonal Change in the Drought Response of Wood Cell Development in Poplar,” Tree Physiology, Vol. 27, No. 7, 2007, pp. 985-992. doi:10.1093/treephys/27.7.985

[10] M. Confalonieri, A. Balestrazzi and S. Bisoffi, "Genetic Transformation of Populus nigra by Agrobacterium tumefaciens,” Plant Cell Reports, Vol. 13, No. 5, 1994, pp. 256-261. doi:10.1007/BF00233315

[11] M. Nishiguchi, K. Yoshida, T. Mohri, T. Igasaki and K. Shinohara, "An Improved Transformation System for Lombardy poplar (Populus nigra var. italica)," Journal of Forest Research, Vol. 11, No. 3, 2006, pp. 175-180. doi:10.1007/s10310-006-0203-1

[12] L. Yi and D. Li, “A Study on Tissue Culture Technique of Populus nigra var. thevestina $\times(P$. diversifolia $+P$. tomentosa)," Journal of Gansu Agricultural University, Vol. 37, 2002, pp. 180-184.

[13] Y. Tao, F. Li and Y. Li, "Establishment of Tissue Culture Regeneration System of Populus nigra var. thevestina," Journal of Northwest A\&F University, Vol. 37, 2008, pp. 203-207.

[14] L. Zhao, L. Xu, S. Shi and C. Wu, "Establishment of 
Tissue Culture Regeneration System for Populus nigra $\times$ P. pyramidalis," Protection Forest Science and Technology, Vol. 2008, No. 6, 2008, pp. 22-24.

[15] T. Mohri, N. Yamamoto and K. Shinohara, "Agrobacterium-Mediated Transformation of Lombardy poplar (Populus nigra L. var. italica Koehne) Using Stem Segments,” Journal of Forest Research, Vol. 1, No. 1, 1996, pp. 13-16. doi:10.1007/BF02348333

[16] T. Murashige and F. Skoog, "A Revised Medium for Rapid Growth and Bioassays with Tobacco Tissue Culture,” Physiologia Plantarum, Vol. 15, No. 3, 1962, pp. 473-497. doi:10.1111/j.1399-3054.1962.tb08052.x

[17] A. Cavusoglu, Z. I. Altas, K. Bajrovic, N. Gozukirmizi, A. Zehir, "Direct and Indirect Plant Regeneration from Various Explants of Eastern Cottonwood Clones (Populus deltoides Bartram ex Marsh.) with Tissue Culture,” African Journal of Biotechnology, Vol. 10, No. 16, 2011, pp. 3216-3221.

[18] R. Yadav, P. Arora, D. Kumar, D. Katyal, N. Dilbaghi and A. Chaudhury, "High Frequency Direct Plant Regeneration from Leaf, Internode, and Root Segments of Easter Cottonwood (Populus deltoids)," Plant Biotechnology Reports, Vol. 3, No. 3, 2009, pp. 175-182. doi:10.1007/s11816-009-0088-5

[19] F. E. Sherif and S. Khattab, "Direct Shoot Regeneration from Leaf, Root and Stem Internode Segments of Male Poplar Trees and the Molecular Analysis of Variant Regenerated Plants," Journal of American Science, Vol. 7, No. 8, 2011, pp. 200-206.

[20] A. K. Thakur and D. K. Srivastava, "High-Efficiency
Plant Regeneration from Leaf Explants of Male Himalayan Poplar (Populus ciliata Wall.)," In Vitro Cell Developmental Biology-Plant, Vol. 42, 2006, pp. 144-147.

[21] T. Ramanathan, K. Satyavani and S. Gurudeeban, "In Vitro Plant Regeneration from Leaf Primordial of GumBearing Tree Aegle marmelos,” E-International Scientific Research Journal, Vol. 3, No. 1, 2011, pp. 47-50.

[22] A. Tanaka, N. Shikazono and Y. Hase, "Studies on Biological Effects of Ion Beams on Lethality, Molecular Nature of Mutation Rate, and Spectrum of Mutation Phenotype for Mutation Breeding in Higher Plants,” Journal of Radiation Research, Vol. 51, No. 3, 2010, pp. 223-233. doi:10.1269/jrr.09143

[23] S. Arase, Y. Hase, J. Abe, M. Kasai, T. Yamada, K. Kitamura, I. Narumi, A. Tanaka and A. Kanazawa, "Optimization of Ion-Beam Irradiation for Mutagenesis in Soybean: Effects on Plant Growth and Production of Visibly Altered Mutants,” Plant Biotechnology, Vol. 28, 2011, pp. 323-329. doi:10.5511/plantbiotechnology.11.0111a

[24] A. Tanaka and Y. Hase, "Establishment of Ion Beam Technology for Breeding,” In: Q. Y. Shu, Ed., Induced Plant Mutations in the Genomics Era, Food and Agriculture Organization of the United Nations, 2009, pp. 243246.

[25] M. Hajika, K. Igita and K. Kitamura, “A Line Lacking All the Seed Lipoxygenase Isozymes in Soybean [Glycine max (L.) Merr.] Induced by Gammaray Irradiation,” Japanese Journal of Breeding, Vol. 41, 1991, pp. 507-509. 